\title{
Public Health in Europe: Power, Politics, and Where Next?
}

\author{
David Stuckler PhD, MPH, ${ }^{1}$ \\ Sanjay Basu MD, MPH, ${ }^{2}$ \\ Martin McKee MD, DSc ${ }^{3}$
}

\begin{abstract}
Health policy in Europe is at a crossroads. Longstanding challenges, such as persisting social and geographical inequalities, ageing populations, and rising burdens of chronic diseases, are being compounded by new, global threats, such as pandemic influenza and crises in the world's financial markets. Significant improvement in the health of Europe's population has been driven by factors both inside and outside the health sector. Key obstacles to improving population health in Europe result from underlying failures to overcome political and economic issues, including those shaping healthcare financing and delivery systems. How can the public health community respond to these challenges? This paper discusses three examples of how power and politics have shaped the world in which public health works. The focus on individual risk factors diverts attention from underlying determinants, such as the dominance of the market in healthcare, and the political decision to favour a rapid transition from communism in the 1990s. Effective public health policy requires addressing these political forces, seeking to understand the dominant paradigms, how they have been defined and shaped, and how they might be changed. Their effects are often subtle but powerful, shaping the language that is used, the assumptions that are made, and the rules that are implied. We can formulate key policy options to help improve health outcomes by reshaping the critical forces that affect public health risk factors among those populations currently most burdened by significant disease in Europe today.
\end{abstract}

Key Words: Europe, Public Health, political economy, social determinants, medical care

\footnotetext{
${ }^{1}$ Oxford University, Department of Sociology, London School of Hygiene \& Tropical Medicine.

${ }^{2}$ University of California San Francisco, Department of Medicine; San Francisco General Hospital, Division of General Internal Medicine; Email sanjay.basu@ucsf.edu

${ }^{3}$ London School of Hygiene \& Tropical Medicine ; European Observatory on Health Systems and Policies; Email: martin.mckee@1shtm.ac.uk
}

Correspondence: David Stuckler at email david.stuckler@chch.ox.ac.uk 


\section{INTRODUCTION}

When asked to write a review of health status and challenges in Europe, our initial thoughts were: it's not so bad. Indeed, it seems quite boringly peaceful. Health in Europe has improved remarkably over recent decades. In the last 50 years, the probability of dying in the first year of life dropped from 1 in 20 to less than 1 in 150, while a fifteen year old's chance of dying before the age of 60 fell from about one-half to one-quarter. Among all age groups and both genders, overall mortality rates have fallen by about 16 percent overall in the region since the 1980s (Figures 1 and 2). Compared with low- and middle-income countries, and even many higher-income nations in Asia and the Americas, Europeans have achieved impressive health gains. European health systems are delivering, for the most part, high quality care in a reasonably equitable manner and at a much lower cost than that in the United States. Most European countries have managed to contain the increase in costs at affordable levels.

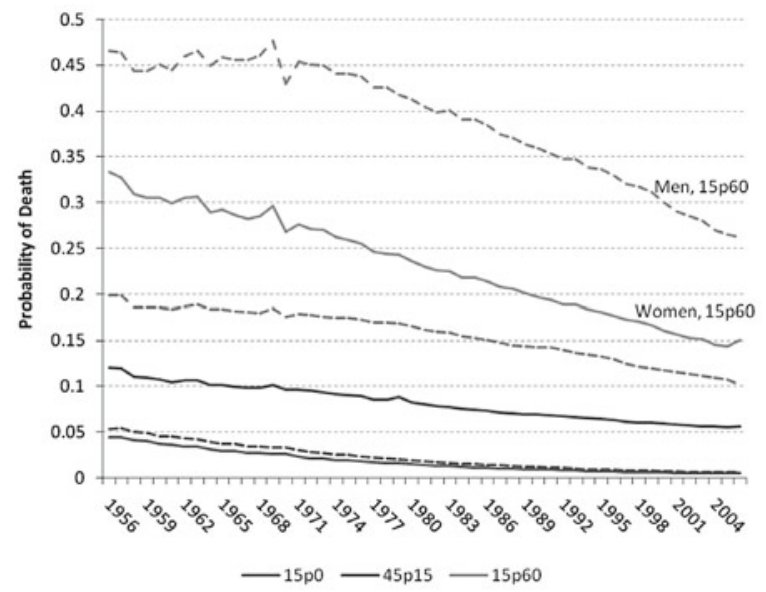

Fig. 1. Trends in Probabilities of Death, by Gender, Europe 1956-2006.

Notes: Source of data: WHO Global Mortality Database 2008 edition. Authors' calculations. Weighted average of $15 \mathrm{p} 0,45 \mathrm{p} 15$ and $15 \mathrm{p} 60$ for EU countries for which data are available, including Austria, Belgium, Denmark, Finland, France, Greece, Germany (West Germany pre-1989), Ireland, Italy, Netherlands, Norway, Portugal, Spain, Sweden, Switzerland, and the United Kingdom. A great proportion of Europe's largest minority group, the Roma of Central and Eastern Europe, continue to be deprived of access to healthcare, ${ }^{7}$ experiencing much worse health outcomes than any other distinct population in Europe. ${ }^{89}$ As Central and Eastern European countries (CEE) began "returning to Europe" following the collapse of the Soviet Union in $1989,{ }^{10}$ the health of its peoples began to converge with their neighbours in Western European countries. However, rapid economic reforms in the former Soviet Union, ${ }^{11}$ which often benefited the few at the expense of the many, resulted in over 3 million excess deaths. ${ }^{12}$ In 2007 , mortality rates in post-Soviet countries were about 20 percent higher than in 1990 (Figure 2). 
Yet on closer inspection, it is clear that Europe still faces many challenges. There is a persisting gradient in health across the socioeconomic spectrum, ${ }^{1,2}$ and in some countries inequalities have widened between those in different income, educational, and occupational classes. ${ }^{3-6}$ Adult men continue to have an 80 percent higher risk of dying between ages 15 and 60 than do women (Figure 1).

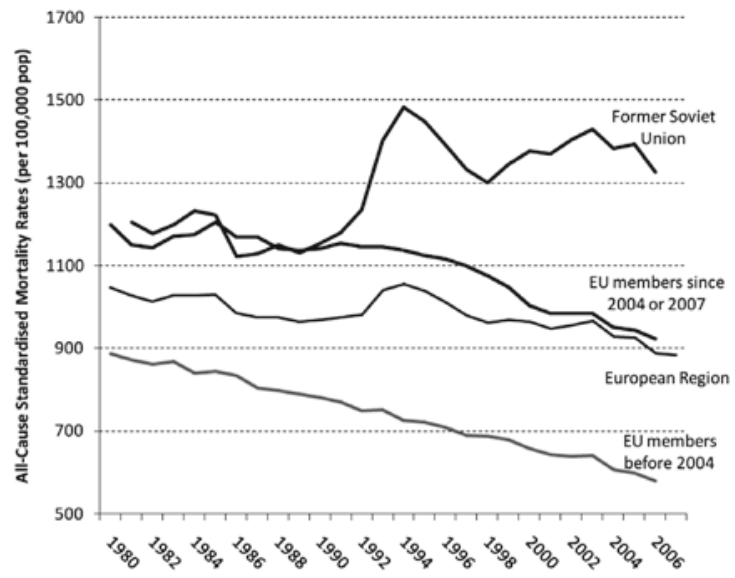

Fig. 2. Trends in Age Standardised All-Cause Mortality Rates, Europe 1980-2007.

Notes: Source of Data: WHO European Health for All Database HFA-MDB 2008 edition: Atlas of health in Europe second edition. Available from URL: http://www.euro.who.int/Document/E91713. pdf (Accessed 14 April, 2010).

There is also evidence that the rate of improvement is slowing. ${ }^{13}$ Although increasing affluence has brought many benefits, in particular advances in medical care, it has also contributed to changes in lifestyle that now have adverse impact on health. Many of these arise from the combination of easy access to cheap energy dense food and environments that both encourage the use of motorised transport and discourage physical exercise. ${ }^{14}$ These changes have been taking place at a time when the once high burden of communicable disease has been falling, giving rise to a phenomenon termed the "epidemiologic transition".

These changes are taking place at a time when Europe is ageing rapidly, as a consequence of increased longevity and falling birth rates. Hopes that the health consequences of ageing might be offset by substantial reductions in the time people suffer from ill-health before dying (i.e., the "compression of morbidity") ${ }^{15}$ may not be realised. ${ }^{16}$ The cost of caring for an older, sicker population may be considerable, especially given upward pressure 
on costs from advances in technology, one of the major drivers of healthcare expenditure in recent decades. ${ }^{17}$ This could pose a challenge to the post-war European consensus on social solidarity in a Europe with a greater share of retired people and ethnic minorities. The risks are exacerbated by tensions being stoked up by ideologically driven politicians and media commentators seeking to reduce the size of the state..$^{18}$

Some of the newer EU member states face additional challenges. One example is tuberculosis, where the greater incidence in Central and Eastern Europe ( 39 per 100,000 population among post-2004 EU members) threatens tuberculosis control in regions of Europe in which incidence rates are currently low (about 9 per 100,000 population in 2007), especially given weaknesses in surveillance in some of the most affected EU Member States. More recently, threats from other parts of an increasingly interconnected world, such as the "Great Recession" of 2008/2009 i.e., the current global economic downturn, and H1N1 influenza outbreaks, show how European public health is becoming dependent on health outside of Europe.

Shifting political pressures further complicate the situation. In response to the current financial crisis, some governments ideologically committed to reducing the role of the state have seized the opportunity to enter an 'age of austerity' and fiscal prudence, campaigning on platforms of curtailing growth in public spending sometimes cutting up to fifteen percent of their health budgets. ${ }^{19,20}$ Others have been forced, against their will, to make similar or greater cuts, with those countries borrowing from the International Monetary Fund (IMF) having been most affected. ${ }^{21}$ The IMF has pursued policies designed to maintain exchange rates and low inflation to protect international lenders at the expense of citizens and governments in the countries affected. ${ }^{22,23}$ Rather than implement radical budget cuts of up to 60 percent called for by the IMF, health ministers in Latvia and Iceland chose to resign..$^{24}$

Thus, we can see that, despite many successes, European public health still faces major challenges: stagnating progress and persistent inequalities, alongside new health threats arising from interconnected global forces and potentially slowing growth in public health budgets. How should Europe's health policy community respond? Most of the remaining challenges are soluble with existing knowledge. The failure lies in the economic and political context in which public health decisions are made and in which new threats to health arise.

The current situation has long historical roots. By the middle of the $19^{\text {th }}$ century, Europe was undergoing the major social and economic transformations of the Industrial Revolution. Markets were more integrated than ever before and by the beginning of the $20^{\text {th }}$ century, international trade 
was even more important than now, as European countries invested heavily in their colonies and throughout the Americas. At the time, there were three major approaches to health: the first focussing on the miasma theory with its focus on sanitation, followed by the germ theories of disease and associated science investigating the biological basis of health and the agents causing disease; thirdly, the expanded capacity of healthcare services, driven by a combination of scientific progress (especially laboratory science, imaging, asepsis, and pharmacology, including anaesthesia) ${ }^{21,25}$; and third, the emergence of epidemiology as a discipline (exemplified by the work of John Snow) ${ }^{26}$ and the development of social medicine (exemplified by the work of Rudolf Virchow). The precise contribution of all of these developments continues to be debated, but all played a part. ${ }^{21,25,27}$

However, until the 1960s, the greatest health gains came about as a consequence of factors outside the health system, and in particular improvements in housing, sanitation, safe water and food supplies, improved nutrition, employment, wages, and education, which caused a steady improvement in living standards and reduced morbidity, for example from tuberculosis. ${ }^{28}$

Today we face a similar situation. We have undergone an intellectual and economic revolution that has transformed our working lives and habits, producing profound inequalities yet interconnecting us more than ever before. ${ }^{29,30}$ Unlike in the past, however, the burden of disease is increasingly chronic and human-produced, resulting from lifestyles that are influenced by changing social and environmental conditions. ${ }^{14}$ The past century has seen great advances in medicine. These include advances in the understanding of disease, often leading to the use of important discoveries and successes such as Helicobacter eradication to prevent peptic ulcer diseases, the development of safe and effective drugs to treat common conditions such as hypertension, diabetes and mental disorders, and an ever growing number of vaccines, including products that reduce the risk of cancer.

However, the scale of this success now poses problems for the pharmaceutical industry that has led this process. It has developed on the basis of a model that is now seen as unsustainable, whereby a progression of high revenue "blockbuster" drugs, each costing vast sums of money to develop, are offered to patients with common chronic disorders (such as hypertension, chronic airway disease, or arthritis). Patients are typically introduced to these drugs when they reach middle-age and will continue to consume them for the rest of their lives. This model allows the drug companies to sell their products at prices that are affordable but sufficient to recoup their investment, as well as a handsome profit. Put simply, with the exception of cognitive decline, there are very few common conditions left for which new 
treatments are needed. As a consequence, companies have focused on niche products, such as treatments for cancer, appropriate for only a small number of patients (often reduced even further by improved knowledge of cellular characteristics such as receptor status), which will prolong life for perhaps a few months. The resulting products must then be sold at prices that many healthcare funders view as prohibitive, especially where they achieve limited extension of life and little reduction in suffering, often for patients of already advanced age, yet at the same time, proven effective measures of prevention are left grossly underfunded..$^{15}$

Public health confronts the same choices about how to respond to the new public health challenges in Europe: push for further research in the basic sciences to understand more about the aetiology and treatment of disease; focus on the expansion of healthcare services where there is evidence of inadequate response to need; or reinvigorate efforts to address the social determinants of disease. Of course, these options are not mutually exclusive and all are needed to some extent. But as in the $19^{\text {th }}$ and early $20^{\text {th }}$ century, the first two options have continued to dominate discussion of health policy, perhaps because the third seems vague, long-term (almost invariably bringing results that extend beyond the electoral cycle), supported by inadequate evidence, and confronted by powerful vested interests.

This imbalance is apparent when contrasting the relatively lukewarm response by institutions beyond the traditional public health community to the report of the World Health Organization (WHO) Commission on Social Determinants of Health ${ }^{31}$ while the WHO Commission on Macroeconomics and Health was greeted with enthusiastic response. The latter emphasised the role of health as a stimulator of economic growth. From this perspective, healthcare and public health become instruments of economic gain, delivered not through public initiatives but through a market-based set of interventions to expand profits and financial activity (namely, the World Bank's Health Sector Reform model). ${ }^{32}$ The Commission on the Social Determinants of Health report, on the other hand, argued that social inequalities were killing people on a grand scale. ${ }^{31}$ Rather than focusing exclusively on economic growth as a goal, this report indicated that inequality-generating policies of bodies such as the IMF were responsible for maintaining millions in poverty while a few were able to profit enormously. These policies include promoting public wage-ceilings to provide cheaper labour and increase profits ${ }^{21,32,33}$ in support of increasingly private forms of investment. $22,33,34$ Thus, while the scientific arguments underpinning both reports may be equally valid (although the Commission on Macroeconomics and Health has been critiqued by some economists), ${ }^{35}$ the implications for political economy differ considerably. 
In this paper, we argue that the new public health should in addition to promoting implementation of high standards of prevention methods available, should also be strategic, putting power and politics back at the centre of public health analysis in a way that can resolve the discrepancy highlighted by the difference between the reports of these two commissions. Progress on key challenges facing European public health will depend on the extent to which the European public health community can engage with the political economy of the world it inhabits. It is not enough to deal with the immediate causes of ill health; instead public health professionals must ask why things are as they are? What are the assumptions underlying how we organise society? Who sets the rules, and are they fit for their purpose? After reviewing briefly the determinants of health in a population, we illustrate our arguments with three examples: the individualisation and medicalisation of risk factors; the dominance of free market epidemiology in health systems; and the political transition in Eastern Europe and the persisting East-West health gap. We conclude with recommendations for a new public health perspective that would put power and politics at the centre of our debates and analyses.

\section{THE DETERMINANTS OF POPULATION HEALTH}

The burden of disease in a population reflects the influence of a series of interacting factors lying along a causal pathway. One way to conceptualise the determinants of health is in terms of immediate, proximal and underlying factors (a distance metric), acting at different levels of influence (e.g., individual, family, community, and population) and carrying varying degrees of power (a strength metric).

A large body of research, both epidemiological and biological, has identified the role of various immediate risk factors in the aetiology of many individual diseases. These risk factors include genetic and environmentally determined physiological factors, such as lipid and blood pressure levels. These are in turn influenced by proximal factors, sometimes referred to as lifestyle factors. Examples of the latter include diet, alcohol and tobacco use, and physical activity, as well as biological factors that can, to varying degrees, be attributed to the proximal factors (often interacting with genetic susceptibility), such as high blood pressure and cholesterol. Proximal and immediate risks frequently interact with certain personal behaviours, thereby increasing the risk of a variety of diseases acting through different biological mechanisms. 
One example is tobacco use, whereby those who smoke (or inhale tobacco smoke from others) are exposed to substances such as nitrosamines, which act as carcinogens creating genetic mutations. Concurrently, carbon monoxide displaces oxygen from haemoglobin while other components of smoke impair endothelial function, increasing the risk of coronary artery disease. Yet, knowing these immediate and proximal risks tells us nothing about why people smoke (or how to intervene). As many philosophers have noted: People make choices but not always in the circumstances of their own choosing. Thus, there are also a range of distal factors leading to behavioural choices such as tobacco use. Smoking rates are strongly socially patterned, at present concentrated among the poor and the least well educated in rich countries and among young urban dwellers in poor countries. These patterns reflect the interplay of a wide range of distal factors acting at both individual and societal levels, including social norms, health beliefs, economic and employment circumstances, and marketing by tobacco companies. Overall, however, the immediate and proximal risk factors can account for a large fraction of the burden of disease, in part, because they reflect the social conditions in which people live.

One determinant of population health that has previously received rather less attention is healthcare. Historically there has been considerable scepticism about its contribution to population health in Europe. Writing in the 1960s, McKeown argued that most of the improvements in mortality over the previous century and a half had preceded the introduction of effective medical care and were instead due to improved living conditions, in particular nutrition. ${ }^{27}$ In the 1970s, Cochrane and colleagues attempted to evaluate the impact of health spending on health outcomes, finding little or no effect of medical care on mortality rates across countries. ${ }^{36}$ There is considerable historical evidence that the major declines in infectious diseases predated the development of effective medicines and were instead due to a combination of improved living conditions and public health measures such as improved sanitation, food safety and immunization. It was only in the late 1940s and 1950s that effective and safe drugs became available to prolong life for those suffering from many common diseases. Initially antibiotics, followed by a growing list of treatments for common non-communicable diseases (NCDs), such as hypertension and chronic obstructive airways disease, as well as others that, while less obviously life saving, greatly improved quality of life, such as non-steroidal antiinflammatory drugs for arthritis and neuroleptics and antidepressants for severe mental illness. At the same time, the development of new and safe vaccines greatly reduced the risk of a number of potentially life-threatening or disabling diseases, such as measles and polio.

Consequently, it was only from the mid-1960s onward that healthcare really began to make a difference to overall mortality rates, a phenomenon 
observable from a comparison of the United Kingdom, where modern healthcare was being introduced, and the Soviet Union, where it was not. ${ }^{37}$ By the 1980s, it became possible to estimate its actual contribution to mortality, using the new concept of avoidable mortality (that is, mortality that should not occur in the presence of timely and effective healthcare). Conceived in the US, it identified that portion of mortality that should be amenable to medical intervention. ${ }^{38}$ This was subsequently adapted by researchers in Europe ${ }^{39,40}$ and is now used widely in comparisons of healthcare performance. ${ }^{41,42}$ Deaths from these causes have fallen markedly in recent decades in European countries, to a substantially greater degree than other causes of death, and much faster than in the US. ${ }^{42}$ Consequently, they now account for only between 7 and 10 percent of all deaths across Europe. ${ }^{40}$

Nonetheless, considerable variations remain in mortality amenable to medical care and, in general, the countries of Central and Eastern Europe, and especially the countries of the former Soviet Union, still lag far behind. However, the implication is that while future developments in personal care may be able to contribute more to the relief of disability, the scope of contribution to longevity, in the absence of some major unanticipated breakthrough, is likely to be limited and the main challenge must be to ensure that those who can benefit from existing knowledge are able to do so. Fortunately, Europe provides a rich natural laboratory to learn from its diverse national and regional experiences, as different countries with varied institutions and cultures adopt alternative angles to address similar challenges, resulting in differing health outcomes. This makes it possible to catalogue both successes and failures, so determining what should be replicated or abandoned, ${ }^{43}$ a task facilitated by the European research community (in particular schools of public health) and bodies such as the European Observatory on Health Systems and Policies.

\section{RESPONSES TO CURRENT AND EMERGING PUBLIC HEALTH RISKS}

\section{In Search of Common Risks: Individualising Public Health}

How has the public health community responded to the changing nature of European public health risks?

European public health researchers have undertaken countless studies on common proximal risk factors and diagnoses, both individually and in combination: obesity and breast cancer; obesity and diabetes; tobacco and diabetes; diabetes and heart disease. But how much has this body of 
knowledge been applied in public health practice and contributed to the improvement of public health?

Given the current state of knowledge, the potential payoff from this research may be limited. Rarely does it go from description to explanation, let alone the identification of effective interventions. Crucial issues pertaining to the political economy of how decisions are made and how new policies can be developed are rarely even considered.

The case of tobacco control puts the problem in perspective. In the 1950s, Doll and Hill demonstrated the link between lung cancer and smoking. ${ }^{44}$ Little further action was taken in Europe. In 1964, the US Surgeon General's report on smoking put the issue at the forefront of public health discussions. ${ }^{45}$ Debates continued through the 1960s and 1970s in the scientific literature, confounded by spurious scientific findings produced by tobacco companies and pseudo-scientific industry front-groups. During this period, little action was taken regarding tobacco control, even though smoking rates among women, who in many countries had previously smoked only rarely, were increasing rapidly. Concerted action by governments to tackle the industry, under strong pressure and influence of community based advocacy groups and court decisions, was the only factor that made a difference. This led to legislating for warning labels on cigarette packs, bans on smoking in public places, increased taxation, and measures to combat smuggling (in which the leading tobacco companies were often complicit). ${ }^{46,47}$ In a few cases they went even further, as when the Minnesota Attorney General initiated litigation against the industry, leading to the disclosure of millions of their internal documents, casting light on the tactics they had been using to subvert evidence and policies. Thus, tobacco consumption has only dropped substantially more than thirty years after the initial research showed it to cause lung cancer. The toll of decades of inaction, including failure to effectively tackle the tobacco industry, includes millions of excess deaths that even now continue to grow as the tobacco industry expands into emerging markets in Africa and Asia.

Today, similar debates are occurring in relation to nutrition (a key factor associated with the rising prevalence of NCDs. Yet the risks associated with food consumption are even more challenging because the products are not incontestably 'global bads' like tobacco, which had just a few clearly identifiable producers and no benefits. Even the worst nutritional products, such as carbonated drinks, can be presented as being tolerable in moderation, frustrating efforts such as taxation or community bans. Scientific consensus was a precursor for progress in tobacco, but public health is nowhere near this stage with nutrition, given myriad exposures and outcomes as well as 
furious debates between different theorizers about, for example, the optimal strategy for weight loss.

What can the concerned health policy community do about the latest challenges to confront it? More fundamentally, what has happened to the field of public health that it appears so impotent in the face of such an overarching population risk? At least three factors appear to have weakened public health's influence on public policy. First, scepticism about the scientific validity of population-level analysis began to emerge in the 1930s. This dates to Robinson's seminal paper on illiteracy and black ethnicity in the US, ${ }^{48}$ Durkheim's preceding work on suicide, ${ }^{49}$ and Selvin's coining of the term "ecologic fallacy" in the 1950s - methodological concerns that subsequently filled epidemiology textbooks..$^{50}$ Not just public health, but most of the social sciences were driven to focus on individuallevel analysis. ${ }^{48}$ This approach to understanding society, putting primacy on the individual's experience, ${ }^{51}$ was most clearly enshrined in economics, in the form of methodological individualism.

At the same time, public health lost touch with its analytical roots, focusing instead on describing a few risk factors - an orientation that was locked-in through the development of surveys and establishment of cohorts. One impetus for this development was the seminal Framingham heart study in the 1960s, which showed how the risk of a major cardiovascular event (heart attack or stroke) could be estimated from knowledge of age, gender, and results of a few laboratory tests. Instead of thinking about underlying social explanations for those laboratory results, public health analysis came to focus on the results themselves as proximal factors for analysis. ${ }^{52,53}$ Surveys and instruments abounded to quantify these factors, shrinking the scope of inquiry for $\mathrm{PhD}$ students and researchers to those variables which were available from standardised data sets whose mining became the basis for academic careers and, in some cases, entire institutes.

As a consequence, the field of public health has shied away from analyzing political factors, romanticising the notion of the 'independent' epidemiologist. ${ }^{51,54}$ In its ideal form, as a scientist in pursuit of objective scientific truths, the epidemiologist would free him or herself from outside influences such as political or economic ideology. ${ }^{55}$ Nothing could be further from the truth, or more dangerous. In economics, Keynes famously pointed out that practical men, who believe themselves to be quite exempt from any intellectual influence, are usually the slaves of some defunct economist. That is where the danger lies. Epidemiologists, neglecting whatever unperceived influences lie behind their work, are unable to mitigate them. Instead, if we account for the intimate relationship between 
the production and structure of new knowledge and the holding of power, ${ }^{56}$ we could identify and make transparent the values behind studies - from conflicts of interest to the very nature of the questions being asked - and act to prevent them from impinging on the research design, approaches, or investigations we consider relevant and interesting.

While the choice of risk factors may seem value-free, it is not. The production of knowledge by epidemiologists interacts powerfully with the political environment, affecting power struggles in politics. For example, as research focuses on individual-level risk factors, it does so at the expense of other explanations, creating a skewed understanding of disease that facilitates political decisions that disregard the chains of disease causation and the most powerful channels for intervention. In short, implications with value-free, apolitical studies do not exist, and the public health community should recognise this fact more explicitly in order to improve its scope of investigation and effectiveness."

Controlling risks requires thinking about why people are exposed to them. In the case of smoking, public health analyses the effects of smoking, but less often the reasons that people smoke. To accomplish the latter task, a theoretical model is required; the theoretical 'black-box' of chronic disease epidemiology is inadequate. ${ }^{52,53}$ Explanations such as "low socioeconomic status", based on correlations, do not suffice as explanations; they are only descriptions. Attributing behaviour to 'psycho-social' stress is similarly nebulous (which may explain why it has been so readily promulgated by the tobacco industry). Economics offers potential insights through rational-addiction models and rates of time-discount; psychology and sociology similarly offer theoretical frameworks through which to test carefully hypotheses that can lead down a trajectory to effective social intervention. However, it has become difficult for the public health community to engage as an equal in some of the leading contemporary debates in economics. Public health analysts that do address these issues, such as those relating income inequality to health (referred to by the British Medical Journal as a "big idea" in public health $)^{57}$ tend to be met with scepticism by economists, many of whom are dismissive of public health research. This is in part because of a perceived failure by the latter to employ some of the more sophisticated methodologies for dealing

\footnotetext{
* To be clear, we are not arguing for subjectivity in science. Researchers should strive to be completely objective, divorcing themselves from ideology, interests, or preferences in the data collection and analysis process. However, we can never be politically neutral in our choices about what to study.
} 
with confounding factors (where insights from econometrics have only minimally been integrated into biostatistics texts). As Deaton, in a paper in a flagship economic journal put it euphemistically:

The literature that is reviewed in this paper comes from a number of fields other than economics, particularly epidemiology, public health, sociology, psychology, and history. Different fields have different styles of presenting theory and evidence, as well as different standards for what counts as credible evidence. Nevertheless, the ideas are often important and should not be dismissed by economists, if only because they are widely accepted by many policy makers and by scholars in other disciplines, and economists need to confront, not ignore, them. In this spirit, it is worth presenting material that is not fully worked out theoretically nor convincingly demonstrated empirically. Economists can make important contributions to this work, and in turn are likely to benefit from other social scientists' sometimes well-argued skepticism of economists' methodologies and prejudices. ${ }^{13}$

The limitations of our approaches not only apply to investigation, but also to policy. While public health researchers increasingly study what policies are effective, they do little to examine how policies are implemented and chosen by governments, or how they are avoided by some governments. Instead of continuing to propound dogmatically the need for intersectoral approaches, "bottom-up intervention" or "good governance", public health must develop methods that are as well-defined as those used when performing epidemiological surveillance studies, which make it possible to implement effectively the policies that result from investigational work.

\section{Markets and Healthcare: Learning the Wrong Lessons?}

The role of market principles has expanded considerably in European health systems in recent decades. Yet all fall far short of the two groups of countries that have long relied extensively on market forces to provide health services, one by design, the other from a lack of resources. These groups are, respectively, the US and low-income countries. There are lessons to be learnt from their experience. They can be compared on four major dimensions of performance set out in the 2000 World Health Report on Health Systems: efficiency, equity, quality and responsiveness. ${ }^{58}$

The US system relies heavily on market elements such as 'consumer choice', managed care, and diagnosis-related groups. It often boasts of having the 'best healthcare in the world'. Indeed, the US does have the best healthcare technology for those who can access it. After age 65, when 
patients become eligible for Medicare (a universal health system for the elderly), cancer survival rates out perform Europe ${ }^{59}$ Thus, that part of the American health system which is publicly funded, and at a significantly higher level of funding than in Europe, does deliver high quality care. There are, alternatively, few positive things to say about health systems in lowincome countries. Medical care is inefficient, inequitable, of poor quality and generally unresponsive to patient and community needs. Costs of care are a leading cause of impoverishment, causing patients to routinely face a lethal dilemma: face bankruptcy or forego life. ${ }^{60}$

Yet the worst features of this system apply not only to these low-income countries. In the US too, healthcare costs are a source of catastrophic expenditure, accounting for one out of every two bankruptcies. The US consistently lags behind Europe in amenable mortality ${ }^{42}$ and outcomes for those too young to receive Medicare coverage are significantly worse than in Europe ${ }^{61}$ It is also a clear outlier in terms of overall spending - spending the most, while getting the least. The WHO rankings, albeit contentious, put the US among the middle-income countries in terms of health system equity.$^{58}$ Furthermore, several poor communities in America experience higher rates of infectious disease, psychosis and premature births than in developing countries. ${ }^{17,62}$

These results are not surprising. In a seminal paper from 1963, the Nobel Laureate economist Kenneth Arrow had demonstrated that free markets do not work for healthcare because the need for medical treatments and services is unpredictable (requiring insurance systems) while at the same time, informed and rational individuals face difficulties in making decisions in their own best interests, instead requiring expert advice (preventing experiential comparison shopping for prices of services of the same quality). ${ }^{63}$ As stated by another Nobel Laureate economist Paul Krugman, "There are no examples of successful healthcare based on the principles of the free market." ${ }^{\prime}$

Remarkably, despite the notable limitations of market-based models in the US and in poor countries, European policymakers often look to the US for inspiration. This is, in part, a reflection of its acknowledged leadership in important public health arenas such as health promotion but also the neoliberal agenda of the 1980s that sought to reduce the role of the state to provide space for private-sector expansion and the partial privatisation of health systems. This is most apparent in the UK, perhaps because of its claim to a "special relationship" with the US. For politicians, there is pressure to 'do something' - sins of commission. Almost every country has its discontents with its health system, seeing that the 'grass is greener' 
elsewhere. This leads some policymakers to pursue short-term political strategies which may bring some immediate benefits but compromise the long-term development of the health system.

Thus far, the results of this process have been mixed. European countries started at different points in their mix of public/private finance and delivery, but by adopting greater market components, show some signs of convergence with each other and the US. One example has been the growing use of public-private contracts, designed to boost the efficiency of care delivery and contain rising costs. In the UK, for example, the additional capacity for elective surgery has decreased patient waiting times, even if at much greater cost than would have been incurred by expanding public provision (to the extent that this can be assessed given England's Department of Health's exclusion of these financial arrangements from freedom of information legislation, citing commercial confidentiality).

In many cases, however, market-based mechanisms have backfired. One example is the UK's Private Finance Initiative, developed as a means of raising capital for building hospitals and healthcare infrastructure, taking advantage of accounting rules that would keep the sums involved outside the official Public Sector Borrowing Requirement. ${ }^{65}$ The idea was that private companies would advance money and be repaid by the government over a long-term period. In hindsight, this was a mistake. It was a short-term political decision, pushing the high costs of financing new hospitals (of questionable necessity) onto future generations. Some countries have now reversed course. For example, Australia harnessed in these growing longterm liabilities by buying back the privately financed hospitals, instead of paying off the interest on its high and outstanding hospital debts. ${ }^{66}$ In the UK, these debts have been, in real terms, compounded by the recent financial crisis. Even though interest rates fell to 1 percent, the government was locked into paying back private companies at much greater rates of over 4 percent, a situation similar to the decades of debt obligations that have resulted in underinvestment in the health systems of low-income countries.

Market mechanisms can play a role in healthcare, and there are some successes. For example, incentive payments introduced for general practitioners in the UK meant to improve the quality of primary care have reduced inequalities. However, the cumulative evidence shows that market mechanisms are no panacea for reducing health service costs or improving quality, fairness or responsiveness to patient needs. If Europe wishes to maintain its existing commitment to solidarity, decision makers ought to be far more critical of unproven strategies to shift health service planning from 
need to demand, turning patients into consumers, and transforming health into a private market good.

\section{POLITICAL CHOICES AND HEALTH CONSEQUENCES: THE UNDERLYING CAUSES OF THE WIDENING EAST-WEST HEALTH GAP}

In setting out to build capitalism out of socialism's ruins, policymakers faced uncharted territory: How to proceed? While countries had moved from capitalism to socialism, few had experience with shifting in the other direction, with the notable exception of China. Many Soviet politicians (and many in the West) wished to seize the opportunity of the 1989 disintegration of the Soviet bloc to enable the socialist countries to make the leap to capitalism in one jump. There were fears that, if they did not, the Communists would return to power.

The debate centred on what was the appropriate pace of transformation. One side of the debate argued for a policy platform, referred to as "Shock Therapy", which called for the rapid privatisation, liberalisation and stabilisation of Communist institutions. As one western advisor fiercely argued, "The need to accelerate privatisation is the paramount economic policy issue facing Eastern Europe. If there is no breakthrough in the privatisation of large enterprises in the near future, the entire process could be stalled for years to come. Privatisation is urgent and politically vulnerable." ${ }^{67}$ As the World Bank's head of mass privatisation implementation wrote, "There was a concern by Russian reformers, above all, that the Communist Party might soon take control again; their desire, therefore was to move as rapidly as possible, i.e., to create 'facts on the ground' that made a market economy irreversible." ${ }^{\prime 8}$ Although the logic was mainly political, there was remarkable consensus among economists. As Lawrence Summers put it, "Despite economists' reputation for never being able to agree on anything, there is a striking degree of unanimity in the advice that has been provided to the nations of Eastern Europe and the former Soviet Union. The legions of economists who have descended on the formerly communist economies have provided advice very similar...the three 'ations' - privatisation, stabilisation, and liberalisation - must all be completed as soon as possible." ${ }^{69}$

Yet there was real dispute. Some economists and politicians, such as Joseph Stiglitz and Mikhail Gorbachev, called for a more gradual approach, like that being pursued in China. Markets would be allowed to evolve gradually to replace underperforming state institutions - "growing out of the plan." ${ }^{\prime 70}$ 
While some of the proposed Shock Therapy reforms, including liberalisation and stabilisation, had been implemented rapidly in Latin American and East Asian countries, the privatisation of an entire economy in a short period was unprecedented. The political logic was arguably the most compelling. "Privatisation, above all, is a highly political decision that private ownership matters and that a capitalist model would serve the populations better than socialism." ${ }^{68}$ As another financial planner noted at the beginning of reform, "There was a period when politics as usual was largely suspended, as one had to be bold." 71

For those in power, the programmes also created an opportunity for the former nomenklatura, the ruling class of communists, to reinvent themselves as capitalists. These programmes enabled them to use their insider networks to gain access to capital and firms at bargain prices. In one of the most heinous schemes, the loans-for-shares programme, bidding for a company with oil assets valued in the billions opened at $\$ 100$ million USD and closed at $\$ 101$ million USD. It is policies such as these which created the famed Russian oligarchs and led to an unprecedented rise in both Russia's billionaire index and Gini coefficient."

How would health be affected? These programmes were expected to have at least two major impacts on health: first by increasing job insecurity and job losses, with their known consequences for health, and second, by dismantling the Soviet-era cradle-to-grave welfare system at a time when people were suffering the most. As Noreena Hertz, at the time working for the World Bank as an economist overseeing mass privatisation in the Russian Federation, explained:

"... the famous economists advising the Russians, including my bosses, acted as if they had a clear blueprint in their pocket. Privatize, open up your markets, slash your public expenditure and you will become a reflection of America was their policy advice.... Of course anyone who had spent any significant length of time in Russia would have realized not only how unrealistic this advice was but also would have become increasingly concerned about the costs that these steps would impose. With the specific task of working on developing the Russian privatization program I soon recognized both. What would happen I asked my Washington bosses when under unbearable financial pressure the

\footnotetext{
* Gini coefficient: An economic measure of inequality of income distribution of income/wealth at a particular point in time, used to compare changes in income distribution within a country or between countries. The index varies between 0 and 1.0; and 1 indicates complete inequality. [URL: http://go.worldbank.org/3SLYUTVY00 (11April, 2010).]
} 
factories I was spending time in had to lay off thousands of their employees? What would happen to the healthcare, the schools, the sanatoriums that these factories were providing? Not just to their workers but to the entire locality when there were no social safety nets in place? 'Don't worry about all that' I was told, 'the market will sort it out'.'"'1

As one World Bank economist put it, "The central premise is that before long-run gains in health status are realised, the transition towards a market economy and adoption of democratic forms of government should lead to short-run deterioration." ${ }^{\prime 2}$ While the effects of the Shock Therapy programmes on the economy are still being debated, ${ }^{73-76}$ their impacts on healthcare and health are relatively clear. ${ }^{11,77}$ In former Soviet countries, there was an attempt to move everything to the market quickly after the fall of the Soviet Union, emulating a low-income country model. ${ }^{78}$ Although Soviet principles of universal care were retained, costs were shifted onto patients; care ceased to be guaranteed at the point of service and instead became almost entirely funded from out-of-pocket expenditures. One expert described the changes as "tortuous, problematic, and confusing", noting further that, "as a general rule, these reforms have not been effective...[and] the failures of such reforms have contributed to health problems in the former Soviet Union and Eastern Europe." ${ }^{\text {"79 }}$ Another put it, "The market was perceived as a panacea for resource shortages and the other ills of the system. It has not proved to be so...." ${ }^{78}$ The consequences were soon apparent. The Soviet system had never managed to adapt to the epidemiological challenges emerging in the second half of the $20^{\text {th }}$ century,$^{80}$ but the speed of change overwhelmed it. There were increasing deaths that should be amenable to healthcare (including a 300 percent rise in deaths from diabetes among persons between ages 15 and 49), ${ }^{37}$ rises in out-of-pocket payments, and growing barriers to healthcare access (especially among the poor). ${ }^{81,82}$

However, the greater impact of rapid free-market reforms on health resulted from triggering a rise in psychosocial stress (specifically, what Durkheim had described as anomie), unemployment and hazardous drinking..$^{83-87}$ Attempts to privatise the entire economy within a two-year timeline delivered a major shock to society - increasing unemployment and job insecurity (both in state-owned firms and privatised firms), led to capital flight, and undermined social safety nets. ${ }^{11}$ Unstable employment led to much higher risks of death ${ }^{85}$ than was seen with unemployment in Western European countries ${ }^{88,89}$ At the same time, hazardous drinking, in part driven by reductions in prices and increased supply, especially of a variety of very strong alcohol products such as aftershaves, gave desperate people an easy means of their own self-destruction. ${ }^{86,90}$ 
One comparison puts the effects of the contrasting approaches in perspective. Western advisors chided Russia's neighbour, Belarus, for its slow pace of privatisation (10 percent of firms by 1996), calling it a "Soviet theme park." However, while mortality trends in Belarus and Russia had been very similar since the 1960s, only in the early 1990s did the overall all-cause mortality rate begin to diverge (Figure 3 ). Russia's age-standardised mortality rate rose more than 40 percent, while Belarus continued on its slow deterioration, increasing steadily by about 10 percent. This pattern was observed throughout the post-Soviet region: more rapid reformers experienced greater rises in all-cause working-age male mortality rates, ${ }^{11}$ as well as alcohol-related death rates, suicide rates and ischaemic heart disease death rates. ${ }^{91}$

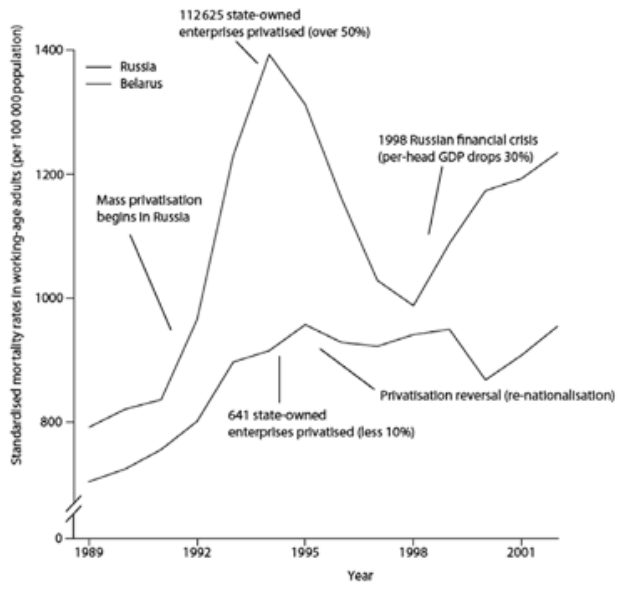

Fig. 3. Mass Privatisation and Adult Male Mortality Rates in Belarus and Russia.

Notes: Age-standardised mortality rates are from the UNICEF TransMonee Database, 2005 edition. Russian state-owned enterprise privatisation data are from the 1997 Russian Economic Trends report version, and Belarus state-owned enterprise privatisation data are from the World Bank 1997 Belarus Country Economic Memorandum. These data are available at the World Bank statistical yearbook (1998): http://www.worldbank.org/ecspf/PSDYearbook/XLS/. See EBRD transition report series for similar estimates.

Source: Stuckler et al. ${ }^{11}$ Available from URL: http://www.thelancet.com/journals/lancet/article/ PIIS0140-6736(09)60005-2/fulltext\# (Accessed 14 April, 2010).

There were also long-term health consequences of rapid privatisation. Through pressure from Western advisors, especially the IMF, ${ }^{22,77}$ the Soviet tobacco and alcohol monopolies were privatised. This enabled industries to circumvent taxation and regulations, ${ }^{92,93}$ and ultimately deliver more efficient drugs to the population, at a time when stress levels were 
exceedingly high.${ }^{94}$ The devastating health consequences of the post-Soviet crisis are even more troubling when compared with other major economic crises, such as the Great Depression. In both cases, gross domestic product (GDP) dropped by about 30 percent. However, in the Great Depression, all-cause mortality rates dropped by about 10 percent, while in the PostCommunist Depression, they rose by about 20 percent. Yet the US of the 1920s and 1930s was very different from the former Soviet Union in the 1990s, in two important respects. First, in 1919 the US had introduced prohibition against alcohol, and while alcohol could still be obtained, it was much more difficult to do so. Second, President Franklin D. Roosevelt implemented the New Deal, a government program that created jobs and provided important social safety nets, notably the Social Security Act of 1935. ${ }^{95}$ The available evidence suggests that economic downturns have mixed effects on health, tending to increase suicides and reduce road traffic fatalities, but that, overall, the health risks depend crucially on the extent to which governments control risks such as alcohol and maintain employment, social and health security. ${ }^{96}$

It is unrealistic to believe that public health advocacy could have avoided the appalling effects of rapid transition in the post-Soviet region. However, had Health Impact Assessment ${ }^{97}$ been an institutionalised and independent component of the economic policies pursued by the international financial agencies during this period, there would at least have been a voice calling for caution, pointing to the likely human toll and so providing some counterbalance to the vociferous campaigners in favour of Shock Therapy. Whenever politicians seek short-term fixes, urging radical economic reforms, public health must identify potential negative health effects, strategies for mitigating them, and, where possible, demonstrate the strength of the evidence behind these decisions (even if that evidence lies outside public health). The ongoing consequences to European public health are clear: today's persistent East-West EU health gap is a legacy of these political decisions.

\title{
TOWARDS A POLITICAL ECONOMY OF HEALTH IN EUROPE
}

\author{
"Medicine is a social science, and politics nothing \\ but medicine at a larger scale." \\ Rudolph Virchow, ${ }^{98} 1848$
}

Today, Virchow's statement might also read in reverse: "Social science is medicine, and medicine is nothing but politics at a larger scale." The practice of medicine cannot be apolitical; nor can politics be separated from its impacts on health. 
Nearly all of the remaining challenges to the health of Europeans do not derive from a lack of evidence. Instead, they relate to a narrow set of economic and political decisions, benefiting the few over the many. Therein lies the key challenge to European public health: how to confront threats from political and economic decisions. Public health is, intrinsically, about making the invisible visible. It can do much by drawing attention to the complex paths from political and economic decisions and the health of nations; studying the immediate causes of disease alone is insufficient and, arguably, counter-productive from a political economy perspective.

If an explicit goal of European public health is to narrow growing health inequalities, thus achieving 'Health for All', the individual focus of public health will not be enough. Behind social inequalities are people, in positions of influence, making decisions that reduce or perpetuate inequalities. How should we influence these macroeconomic and social decisions that profoundly affect health and healthcare? As Geoffrey Rose famously noted in a different context, if we wish to address European public health, we must ask why some populations are healthy and others sick. ${ }^{99}$ Public health has not risen to this challenge.

These failures come into focus in light of the challenges posed by certain policy nexuses, such as obesity and the Common Agricultural Policy; tobacco and the World Trade Organization; and medicines and the Trade Related Aspects of Intellectual Property Rights Agreement. These are the "causes of the causes of the causes". Important steps have been taken to begin to address them by a few research groups, but they remain a minority in public health and medicine.

Similarly, public health has long recognised the need to address social determinants of health, but public health rarely engages with those who drive these determinants. These include the IMF, the World Bank (beyond its Health, Nutrition and Population division), the World Trade Organization, and representatives of finance and trade ministries. One school of health policy analysis is simple: ask who benefits? And who loses? Follow the money, and we will find the root cause of many of our most intractable problems. Public health must engage with powerful international financial institutions as the key means of interaction with the powerful corporate and political interests that they represent, but it must do so within a clear set of rules of engagement, based on explicit principles, including transparency.

As public health reaches its crossroads, it must decide which path to take. It has reached the end of the road travelled thus far. The report of the WHO Commission on the Social Determinants of Health acknowledges the tension between the status quo of economic policy and maximising the best 
possible public health. ${ }^{31}$ Yet one road ahead, putting politics and power back in analysis, is not new at all. It dates to the early and mid $19^{\text {th }}$ century, when progress was made in sanitation, nutrition and in eliminating poverty, bringing about reductions in tuberculosis at a time before antibiotics had been discovered and in mortality from measles before a vaccine had been developed. Today we stand at the opposite end of the spectrum. We have pushed medicine close to its limits but are achieving diminishing returns from the dominant economic development model, as well as medicine itself. We have medical knowledge but lack the imagination that, in the past, had achieved remarkable progress when technology had little to offer.

This may seem radical, but to do otherwise is a riskier strategy, as it allows the public health field to reproduce existing imbalances in power without developing the means to address the challenges that lie ahead. As we enter the third stage of epidemiologic transition, to 'man-made' degenerative diseases, the challenge of combating NCDs and promoting healthy ageing require not only medical technology and public health interventions but also actions that address social conditions. Only when power and politics are at the front of analysis and action, when the needs of the many are principled over the desires of the few, can we break through the 'glass ceiling' of stagnating progress in European public health.

Often papers such as this conclude with recommendations that persons outside public health should take. Instead, we hold a mirror up to ourselves as public health professionals. We recommend the following steps that should be taken within public health, given the lessons from European policy-making in the last half century:

1. We should begin all public health analysis by thinking about who benefits and who loses from the results of a study as well as the decision to implement or not to implement a policy.

2. We should identify our intellectual predispositions as part of our studies. Researchers are only human; they develop hypotheses based on their intrinsic values, attempt to reach a finding that confirms this, and then write up the paper once they find consistent results. Rarely, this can lead to serious abuse, as has been seen in the behaviour of certain researchers of climate change at the University of East Anglia. The very least that should be done is to make this explicit.

3. The two previous steps should form part of expanded conflict of interest statements.

4. The incentive structure embedded in the system of promotion in academic medicine and public health should be refocused to encourage research and scholarship that addresses some of the fundamental 
questions about the distribution of power in society and the relationships between the individual and the state. Mechanisms are needed that reward those whose ideas are innovative yet risky, rather than low risk and predictable, a task that will challenge the inherent conservatism of many reviewers and grant-awarding bodies. In this respect, the National Institute of Health's Pioneer awards to encourage innovative, high-risk ideas ${ }^{100}$ and the recent decision by the Wellcome Trust $^{101}$ to fund individuals rather than projects offer considerable promise.

5. We must explicitly identify the political mechanisms and study the political processes that determine key public health policies-evaluating, at each step, what decisions were made based on which evidence (or lack thereof), and who participated in the decision-making, as well as how the public health evidence weighs in on different aspects of the decision.

6. Health Impact Assessment must be integrated into the decisions that are directed by Ministries of Finance, urging public health practitioners to engage actively with these Ministries as well as with the non-governmental organisations that monitor government action and advocate for change. However, this must incorporate openly debated principles and avoid capture by powerful vested interests.

7. Public health practitioners, teachers, and researchers should be forceful advocates for advancing effective public health and social policies within the political environments in which they live to advance the health of the population they serve.

\section{SUMMARY AND CONCLUSIONS}

The examples discussed in this paper show why public health professionals must engage with the political factors that shape the world in which they work, seeking to understand the dominant paradigms, how they have been defined and shaped, and how they might be changed. Their effects are often subtle but powerful, shaping the language that is used, the assumptions that are made, and the rules that are implied. This can be seen in the focus on individual risk factors that diverts attention from their underlying determinants, the dominance of the market in healthcare, and the presumption in favour of a rapid transition from communism in the 1990s.

Fundamentally, it demands that we continue to seek and expand our search for the causes of disease, and applying the best standards of preventing them, but we should also ask what it is about society that allows those causes to exist and to exert their effects and, ultimately, how they 
might be changed. Progress on the key challenges facing European public health also depends on the extent to which the European public health community can engage with the political economy of the world it inhabits.

Conflicts of interest: None declared.

\section{REFERENCES}

1. Van Doorslaer E, Koolman X. Explaining the differences in income-related health inequalities across European countries. Health Econ. 2004;13:609-28.

2. Judge K, Platt S, Costongs C, Jurczak K. Health inequalities: a challenge for Europe. Discussion paper. London: UK Presidency of the EU; 2006. Available from URL: http://ec.europa.eu/health/ph_determinants/socio_economics/ documents/ev_060302_rd05_en.pdf (Accessed 11 April, 2010).

3. Mackenbach J. Health inequalities: Europe in profile. Erasmus: EU Commission; 2006. Available from URL: http://ec.europa.eu/health/ph_determinants/socio_ economics/documents/ev_060302_rd06_en.pdf (Accessed 11 April, 2010).

4. Albreht T, McKee M, Alexe DM, Coleman MP, Martin-Moreno JM. Making progress against cancer in Europe in 2008. Eur J Cancer. 2008;44:1451-6.

5. Zatonski W, Didkowska J. Closing the gap: Cancer in Central and Eastern Europe (CEE). Eur J Cancer. 2008;44:1425-37.

6. Mackenbach J, Stirbu I, Roskam AJ, Schaap MM, Menvielle G, Leinsalu M, et al. Socioeconomic inequalities in health in 22 European countries. N Engl J Med. 2008;358:2468-81.

7. European Roma Rights Centre. Ambulance not on the way. Budapest: ERRC; 2006. Available from UEL: European Roma Rights Centre. Ambulance not on the way. (Accessed 11 April, 2010).

.8 Kósa Z, Széles G, Kardos, L, Kósa K, Németh R, Országh, et al. A comparative health survey of the inhabitants of the Roma settlements in Hungary. Am J Public Health. 2007;97:853-9.

9. Rechel B, Blackburn CM, Spencer NJ, Rechel B. Access to health care for Roma children in Central and Eastern Europe: findings from a qualitative study in Bulgaria. Int J Equity Health. 2009;8:24.

10. Wedel J. Collision and collusion: the strange case of Western aid to Eastern Europe. New York: Palgrave ${ }^{\mathrm{TM}} ; 2001$.

11. Stuckler D, King L, McKee M. Mass privatisation and the post-communist mortality crisis. Lancet. 2009;373:399-407.

12. Cornia GA, Paniccia R (editors). The mortality crisis in transitional economies: New York: Oxford University Press, USA; 2000.

13. Deaton A. Health, inequality and economic development. J Econ Lit. 2003; XLI:113-58.

14. Omran AR. The epidemiologic transition: a theory of the epidemiology of population change. Milbank Mem Fund Q. 1971;29:509-38. Available from URL: http://www.ncbi.nlm.nih.gov/pmc/articles/PMC2566347/pdf/11246833. pdf (Accessed 11 April, 2010). 
15. Fries JF. Aging, natural death and the compression of morbidity. Bull World Health Org. 2002;80:245-50. Available from URL: http://www.scielosp.org/ pdf/bwho/v80n3/v80n3a12.pdf (Accessed 11 April, 2010).

16. Stuckler D. Population causes and consequences of leading chronic diseases: a comparative analysis of prevailing explanations. Milbank Q. 2008;86:273326. Available from URL: http://www.jstor.org/pss/25434094 (Accessed 11 April, 2010).

17. World Health Organization. Statistical Information System (WHOSIS). Geneva: World Health Organization; 2009. Available from URL: http://www.who.int/ whosis/en/ (Accessed 11 April, 2010).

18. McKee M. Solidarity in a unified Europe. Eur J Public Health. 2008;18:2-4. Available from URL: http://eurpub.oxfordjournals.org/cgi/content/extract/ 18/1/2 (Accessed 11 April, 2010).

19 Blanchflower D. Cameron's dud options. Guardian.co.uk. Guardian News and Media Limited 2009 October 9. Available from URL: http://www.guardian. co.uk/commentisfree/2009/oct/09/cameron-osborne-recession-recoveryinflation (Accessed 11 April, 2010).

20. Brittan S. A cool look at the current deficit hysteria. Financial Times 2009 October 1. Available from URL: http://www.ft.com/cms/s/0/4679c2be-aed011de-96d7-00144feabdc0.html?catid=113\&SID=google (Accessed 11 April, 2010).

21. Easterly W. The white man's burden. Lancet. 2006;367:2060.

22. Stuckler D, Basu S. The International Monetary Fund's effects on global health: before and after the 2008 financial crisis. Intl J Health Serv. 2009;39:771-81.

23. Weisbrot M, Ray R, Johnston J, Cordero JA, Montecino JA. IMF-supported macroeconomic policies and the world recession: a look at forty-one borrowing countries. Washington (DC): Center for Economic Policy Research (CEPR); 2009. Available from URL: http://www.cepr.net/index.php/publications/reports/ imf-supported-macroeconomic-policies-and-the-world-recession/ (Accessed 11 April, 2010).

24. Jolly, D. Latvian health official resigns over cuts. in New York Times (New York, 2009). June 17. Available from URL: http://www.nytimes.com/2009/ 06/18/business/global/18lat.html?_r=1 (Accessed 11 April, 2010).

25. Starr P. The social transformation of American medicine. New York: Basic Books; 1982.

26. Snow J. On the supposed influence of offensive trades on mortality. Lancet. 1856;68:95-7.

27. McKeown T. The role of medicine: dream, mirage or nemesis. In: Mackay L, Soothill K, Melia K, editors. Classic Texts in Health Care. Oxford: ButterworthHeinemann; 1998.

28. Blower S, McLean AR, Porco TC, Small PM, Hopewell PC, Sanchez, et al. The intrinsic transmission dynamics of tuberculosis epidemics. Nat Med. 1995; 1:815-21. 
29. Harvey D. A brief history of neoliberalism. Oxford: Oxford University Press; 2007.

30. Castells M. The rise of the network society. Second ed. Oxford: WileyBlackwell; 2001.

31. Commission on Social Determinants of Health. Closing the gap in a generation: health equity through action on the social determinants of health. Final report of the Commission on Social Determinants of Health. Geneva: World Health Organization; 2008. Available from URL: http://www.who.int/social_ determinants/ en/ (Accessed 11 April, 2010).

32. World Bank. Investing in health. Washington (DC): World Bank; 1993. Available from URL: http://www-wds.worldbank.org/external/default/WDS ContentServer/IW3P/IB/1993/06/01/000009265_3970716142319/Rendered/ PDF/multi0page.pdf (Accessed 11 April, 2010).

33. Giovanni AC, Jolly R, Stewart F. (editors) Adjustment with a human face. Vol 1. Protecting the vulnerable and promoting economic growth. Oxford: Clarendon Press; 1987.

34. Kim JY, Millen JV, Irwin A, Gershman J. Dying for growth: global inequality and the health of the poor. Monroe (Me): Common Courage Press; 2000.

35. Acemoglu D, Johnson S, Robinson J. Disease and development in historical perspective. J Eur Econ Assoc. 2003;1:397-405.

36. Cochrane A, St Leger AS, Moore F. Health service 'input' and mortality 'output' in developed countries. J Epidemiol Community Health. 1978;32:200-5.

37. Andreev EM, Nolte E, Shkolnikov VM, Varavikova E, McKee M. The evolving pattern of avoidable mortality in Russia. Int J Epidemiol. 2003;32:437-46.

38. Rutstein DD, Berenberg W, Chalmers TC, Child CG $3^{\text {rd }}$, Fishman AP, Perrin EB. Measuring the quality of medical care: a clinical method. New Engl J Med. 1976; 294:582-8.

39. Charlton JR, Hartley RM, Silver R, Holland WW. Geographic variation in mortality from conditions amenable to medical intervention in England and Wales. Lancet. 1983;1:691-6.

40. Holland WW. European Community Atlas of Avoidable Death. Oxford: Oxford University Press; 1988.

41. Nolte E, McKee M. Does health care save lives? Avoidable mortality revisited. London: Nuffield Trust; 2004.

42. Nolte E, McKee CM. Measuring the health of nations: updating an earlier analysis. Health Aff. 2008;27:58-71.

43. Rose R. What is lesson-drawing? J Publ Pol. 1991;11:3-30.

44. Doll R, Hill AB. Lung cancer and other causes of death in relation to smoking: a second report on the mortality of British doctors. Br Med J. 1956;2: 107181.

45. US Surgeon General. The reports of the Surgeon General: the 1964 report on smoking and health; 1964. Bethesda (MD): National Institutes of Health; 1964. Available from URL: http://profiles.nlm.nih.gov/NN/B/B/M/Q/_nnbbmq.pdf (Accessed 11 April, 2010). 
46. Joossens L, Raw M. Progress in combating cigarette smuggling: controlling the supply chain. Tob Control. 2008;17:399-404.

47. Joossens L, Raw M. Turning off the tap: the real solution to cigarette smuggling. Int J Tuberc Lung Dis. 2003;7:214-22.

48. Subramanian SV, Jones K, Kaddour A, Krieger N. Revisiting Robinson: The perils of individualistic and ecologic fallacy. Int J Epidemiol. 2009;38:34260.

49. Durkheim E. Suicide. Glencoe (IL): Free Press; 1951.

50. Selvin H. Durkheim's suicide and problems of empirical research. Am J Soc. 1958;63: 607.

51. Diez-Roux AV. Bringing context back into epidemiology: variables and fallacies in multilevel analysis. Am J Public Health. 1998;88:216-22.

52. Susser M, Susser E. Choosing a future for epidemiology: II: From black box to Chinese boxes and ec-epidemiology. Am J. Public Health. 1996;86674-7.

53. Susser M, Susser E. Choosing a future for epidemiology: I: Eras and paradigms. Am J Public Health. 1996;86:668-73.

54. Rothman KJ, Adami HO, Trichopoulos, D. Should the mission of epidemiology include the eradication of poverty? Lancet. 1998;352:810-3.

55. Mackenbach JP. Politics is nothing but medicine at a larger scale: reflections on public health's biggest idea. J Epidemiol Community Health. 2009;63:181-4.

56. Foucault, M. 1980: Truth and power. In Gordon, C., editor, Power/knowledge: selected interviews and other writings, 1972-1977, New York: Pantheon Books, 1980.

57. Smith R. The big idea [Editor's choice]. BMJ.1996;312.

58. World Health Organization. The world health report 2000: health systems: improving performance. Geneva: World Health Organization; 2000.

59. Gatta G, Capocaccia R, Coleman MP, Gloeckler Ries LA, Hakulinen T, Micheli A, et al. Toward a comparison of survival in American and European cancer patients. Cancer. 2000;89:893-900.

60. Xu K, Evans DB, Carrin G, Aguilar-Rivera AM, Musgrove P, Evans T. Protecting households from catastrophic health spending. Health Aff. 2007; 26:972-83.

61. McKee M, Nolte E. Responding to the challenge of chronic disease: ideas from Europe. Clin Med. 2004;4:336-42.

62. NHANES. National Health and Nutrition Examination Survey. Atlanta: Centers for Disease Control and Prevention; 2008 Available from URL: http://www. cdc.gov/nchs/surveys.htm (Accessed 11, April 2010).

63. Arrow KJ. Uncertainty and the welfare economics of medical care. Am Econ Rev. 1963; [reprinted WHO Bull World Health Organ. 2004;82:141-149.] Available from URL: http://www.who.int/bulletin/volumes/82/2/PHCBP.pdf (Accessed 11 April, 2010).

64. Krugman P. Why markets can't cure healthcare. New York Times. 2009 July 25. Available from URL: http://krugman.blogs.nytimes.com/2009/07/25/whymarkets-cant-cure-healthcare/ (Accessed 11 April, 2010). 
65. Atun RA, McKee M. Is the private finance initiative dead? It may have failed in the United Kingdom, but that won't stop it being exported. BMJ. 2005;331: 792-3.

66. McKee M, Edwards N, Atun R. Public-private partnerships for hospitals. Bull World Health Organ. 2006;84:890-6. Available from URL: http://www.ncbi. nlm.nih.gov/pmc/articles/PMC2627548/pdf/17143463.pdf (Accessed 11 April, 2010).

67. Sachs J. Accelerating privatization in Eastern Europe: the case of Poland. A Working Paper. World Bank Annual Conference on Development Economics; 1991 April 25-26th; 1991.Washington (DC). Available from URL: http:// docs.google.com/viewer?a=v\&q=cache:D70OBpQPkQMJ:www.wider.unu. edu/publications/working-papers/previous/en_GB/wp-92/_files/8253083115 9464337/default/WP92.pdf+Sachs+J.+Accelerating+privatization+in+Eastern +Europe:+the+case+of+Poland.+A+Working+Paper.+World+Bank (Accessed 11 April, 2010).

68. Lieberman IW, Kopf DJ. Privatization in transition economies: the ongoing story. Amsterdam: Elsevier; 2008.

69. Pomer M. Introduction.(p 5). In: Klein L, Pomer M. The new Russian transition gone awry. Stanford; Stanford University Press; 2001.

70. Naughton B. Growing out of the plan: Chinese economic reform, 1978-1993. New York (NY): Cambridge University Press; 1996.

71. Hertz N. The role we can play in shaping globalization global challenge for Maastricht University: Speech on the occasion of the Opening Ceremony of the Academic Year 2005-2006. Available from URL: http://www.google.co. $\mathrm{il} /$ search?hl=iw\&source $=\mathrm{hp} \& \mathrm{q}=$ maastricht + university + opening $+2005+$ noreena+hertz\&meta $=\& \mathrm{rlz}=1 \mathrm{R} 2 \mathrm{GGLL} \_$en $\& \mathrm{aq}=\mathrm{f} \& \mathrm{aqi}=\& \mathrm{aql}=\&$ oq $=\& \mathrm{gs} \_\mathrm{rfai}=$ (Accessed 14 April, 2010).

72. Adeyi O, Chellaraj G, Goldstein E, Preker A, Ringold D. Health status during the transition in Central and Eastern Europe: development in reverse? Health Policy Plan. 1997;12:132-45.

73. De Melo M, Gelb A. A comparative analysis of twenty-eight transition economies in Europe and Asia. Post-Soviet Geography and Economics. 1996;37:265-85.

74. De Melo M, Denzier C, Gelb A, Tenev S. Circumstances and choice: The role of initial conditions and policies in transition economies. World Bank Econ Rev. 2001;15:1-31.Available from URL: http://wber.oxfordjournals.org/cgi/ content/abstract/15/1/1 (Accessed 11 April, 2010).

75. King L, Sznajder A. The state-led transition to liberal capitalism: neoliberal, organization, world-systems, and social structural explanations of Poland's economic success. Am J Socio. 2006;112:751-801.

76. King L. Shock privatization: the effects of rapid large scale privatization in enterprise restructuring. Polit Soc. 2003;31:3-30.

77. Stuckler D, King LP, Basu S. International Monetary Fund programs and tuberculosis outcomes in post-communist countries. PLoS Med. 2008;5:e143. 
78. Tragakes E, Lessof, S. Health care systems in transition. In: Tragakes E, editor. Health care systems in transition: Russian Federation. Copenhagen: European Observatory on Health Systems and Policies; 2003.

79. Davis C. Reforms and performance of the medical systems in the transition states of the former Soviet Union and Eastern Europe. Int Soc Secur Rev. 2001;54:7-56.

80. Tulchinsky TH, Varavikova EA. Addressing the epidemiologic transition in the former Soviet Union: strategies for health system and public health reform in Russia. Am J Public Health. 1996;86:313-20.

81. Balabanova D, Falkingham, J, McKee, M. Winners and losers: the expansion of insurance coverage in Russia in the 1990s. Am J Public Health. 2003;93:2124-30.

82. Balabanova D, McKee M, Pomerleau J, Rose R, Haerpfer C. Health service utilization in the former soviet union: evidence from eight countries. Health Serv Res. 2004;39:1927-50.

83. McKee M, Britton A. The positive relationship between alcohol and heart disease in Eastern Europe: potential physiological mechanisms. J R Soc Med. 1998; 91:402-407.

84. McKee M, Nolte E. Lessons from health during the transition from communism. BMJ. 2004;329:1428-9.

85. McKee M, Suhrcke M. Commentary: health and economic transition. Int J Epidemiol. 2005;34:1203-6.

86. McKee M. Alcohol in Russia. Alcohol and Alcoholism. 1999;34:824-829.

87. McKee M, Pomerleau J, Robertson A, Pudule I, Grinberga D, Kadziauskiene K, et al. Alcohol consumption in the Baltic Republics. J Epidemiol Community Health. 2000;54:361-6.

88. Perlman F, Bobak, M. Assessing the contribution of unstable employment to mortality in posttransition Russia: prospective individual-level analyses from the Russian longitudinal monitoring survey. Am J Public Health. 2009;99: 1818-25.

89. Stuckler D, Basu S, Suhrcke M, Coutts A, McKee M. The public health impact of economic crises and alternative policy responses in Europe: an empirical analysis. Lancet. 2009;374:315-23.

90. Gil A, Polikina O, Koroleva N, McKee M, Tomkins S, Leon DA. Availability and characteristics of non-beverage alcohols sold in 17 Russian cities in 2007. Alcohol Clin Exp Res.2009;33:79-85.

91. King L, Hamm P, Stuckler D. Rapid large-scale privatization and death rates in ex-communist countries: an analysis of stress-related and health system mechanisms. Int J Health Serv. 2009;39: 461-89.

92. Gilmore AB, Radu-Loghin C, Zatushevski I, McKee M. Pushing up smoking incidence: plans for a privatised tobacco industry in Moldova. Lancet. 2005; 365:1354-9.

93. Gilmore AB, McKee M. Moving East: how the transnational tobacco industry gained entry to the emerging markets of the former Soviet Union - part I: establishing cigarette imports. Tob Control. 2004;13:143-50. 
94. Gilmore A, Fooks G, McKee M. The International Monetary Fund and tobacco: a product like any other? Int J Health Serv. 2009;39:789-93.

95. Haines MR, Kantor S. Births, deaths and New Deal relief during the Great Depression. Rev Econom Stat. 2007;89:1-14.

96. Stuckler D, Basu S, Suhrcke M, McKee M. The health implications of financial crisis: a review of the evidence. Ulster Med J 2009;78:142-5.

97. World Health Organizaztion. Health Impact Assessment (HIA). Available from URL: http://www.who.int/hia/about/en/index.html (Accessed 11 April, 2010).

98. Virchow R. Der Armenarzt. Medicinske Reform. 1848;18:125-27.

99. Rose G. Sick individuals and sick populations. Bull World Health Organ. 2001; 79:32-8.

100. National Institute of Health. NIH Director's Pioneer Award. Washington (DC). Available from URL: http://nihroadmap.nih.gov/pioneer/index.aspx (Accessed 14 April, 2010).

101. Wellcome Trust Strategic Awards. Available from URL: http://www.wellcome. ac.uk/Funding/Strategic-awards/index.htm (Accessed 14 April, 2010). 